\title{
The Effect of Perceived Value and Satisfaction on Repeat Purchase
}

\author{
Aprihatiningrum Hidayati ${ }^{1 *}$, Ronny Kountur ${ }^{2}$, Siti Nuraisyah Suwanda $^{3}$ \\ ${ }^{1,2,3}$ Sekolah Tinggi Manajemen PPM, Jl. Menteng Raya No. 9-19, 10340, Jakarta, Indonesia
}

\begin{abstract}
Objective - This study set out to examine the effect of perceived value and satisfaction on repeat purchase. Training service companies are competing by encouraging their managers to increase repeat purchase.

Methodology/Technique - Data from a survey of 300 customers of public training are used to scientifically verify the model. Path analysis is used to process the data.

Findings - Results show that perceived value and satisfaction have indirect effect on repeat purchase through the mediating role of service quality. Satisfaction and perceived value are important predictors in enhancing service quality, but do not directly affect repeat purchase. Surprisingly, the direct effect on repeat purchases stems from service quality while recent researches suggest satisfaction is the antecedent. The findings suggest that training service companies should exert all efforts to improve service quality through service delivery training for their employees.

Novelty - Most of literature considers purchase as an attitudinal (namely purchase intention), while this study focuses on behavioural (namely repeat purchase) that consider to be more actual and impactful for companies' sustainability.

Type of Paper: Empirical.

JEL Classification: M3, M31.

Keywords: Path Analysis, Perceived Value, Repeat Purchase, Satisfaction, Service Quality

Reference to this paper should be made as follows: Hidayati, A; Kountur, R; Suwanda, S.T. (2020). The Effect of Perceived Value and Satisfaction on Repeat Purchase, J. Mgt. Mkt. Review, 5(4) 197 - 205. https://doi.org/10.35609/jmmr.2020.5.4(1)
\end{abstract}

\section{Introduction}

Repeat purchase is also known as "customer's repeat purchase" that is when a customer buys again a product manufactured or produced by the same company (Damit et al., 2019). There is a subtle difference between first-time and repeat buyers. It is important to know the differences since it is the basis for developing a marketing strategy (Chua et al., 2016; Ryu \& Han, 2011). Several studies had been done to compare the new customers and the repeat customers (Anwar \& Sohail, 2004; Chi, 2012; Petrick, 2004; Ryu \& Han, 2011), especially in looking at their decision making process and behaviours (Fakeye \& Crompton, 1991; Han et al., 2011; Lee et al., 2009; Lichtenstein et al., 1988). And, in trying to convert from new customers to repeat customers (Payne, 1999). Repeat purchase occurred when customers had previous consumption experience (Fakeye \& Crompton, 1991; Lichtenstein, Bloch, \& Black, 1988).

\footnotetext{
* Paper Info: Revised: September 12, 2020

Accepted: December 31, 2020

* Corresponding author: Aprihatiningrum Hidayati

E-mail: apri.hidayati@gmail.com,apr@ppm-manajemen.ac.id

Affiliation: Sekolah Tinggi Manajemen PPM, Jl. Menteng Raya No. 9-19, 10340, Jakarta, Indonesia
} 
From experience, the customer may either feel satisfied or dissatisfied. Repeat purchases occurred only if they are satisfied using the products or services. In that position, it can be indicated that the customer already has brand loyalty. Service firms have exerted to exploit brand loyalty by revamping both service design and customer experience (Luo et al., 2019). Brand loyalty indicates the deep commitment of customer to rebuy a favour brand or to haunt insistently (Oliver, 1999). Loyalty is attitudinal when it involves an intention to rebuy and to advocate, and behavioural when it is related to repeat purchases (Anton et al., 2017).

Meanwhile, most of recent literatures are focusing on direct relationship between customer satisfaction and repurchase intention (Anton et al., 2007; Ha et al., 2013; Hackman et al., 2006; Han \& Ryu, 2009; Hellier et al., 2003; Jones et al., 2000; Patterson \& Smith, 2003; Patterson \& Spreng, 1997; Zeithaml, 2000). These scholars refer to repurchase in terms of loyalty as an attitudinal or a propensity to rebuy a product, not explicitly refer to a behavioural or an actual behaviour of repeated buying. Therefore, it takes a lot of effort to measure behavioural (not attitudinal) repurchases due to the data limitation.

It has been known that there is a relationship between satisfaction from the first purchase to the repeat purchase. The effect of satisfaction toward repeat purchase may be weak or strong and is due to several factors. It is the intention of this study to know what are those determinants that bestow the degree of relationship between satisfaction from first purchase to repeat purchases. It will help marketing practitioners improve their strategy in gaining more repeat purchasers. Specifically, the following issues will be addressed: 1) Does service quality predict repeat purchase; 2) Does perceived value moderate the link between service quality and repeat purchase; 3) Does satisfaction moderate the link between service quality and repeat purchase.

The remaining part of the paper proceeds as follows: First, a literature review is introduced as a basis for hypothesis development, which forms into a comprehensive model focused on antecedents directly predicted repeat purchase. It is continued by methodology of research used to examine the hypotheses, then the findings and implications. At last, a critical discussion is presented including limitations derived from the study and suggestions for future research.

\section{Literature Review}

Service quality is explained by Parasuraman et al. (1988) as a result of comparing customer expectancy with perceived service performance. The customers' evaluation of the overall service quality depends on the gap between expectancy and the resulting perceived performance. Companies could differentiate themselves from any other companies by providing an excellent service quality (Boshoff \& Gray, 2004). Recent studies prove that service quality has become ultimate competitive advantage (Parasuraman et al., 1988; Rust, Lemon, \& Zeithaml, 2004) and ought to be taken into account as primary criteria in strategic planning (Taylor \& Baker, 1994). Service quality has a positive impact on customer loyalty (Chumpitaz \& Paparoidamis, 2007; Fullerton, 2005; Rauyruen \& Miller 2007) that induce repeat purchases. Moreover, it is a crucial element in establishing repeat purchase (Andaleeb, 1998; Kotler \& Keller, 2016; Taylor \& Baker, 1994; Torres, 2014). Service quality referred to the quality of service, quality of product, and price (Zeithaml \& Bitner, 2003). The satisfaction-service quality link has predominated the literature (Brady and Robertson, 2001; Patterson \& Spreng, 1997). Coherent with the link between service quality and affective constructs, service quality ought to be linked to behavioural consequences such as brand loyalty (Zeithaml et al.,1996). These arguments suggest the subsequent hypothesis:

H1. Service quality predicts repeat purchase

Perceived value is a customer's overall evaluation of the utility of a product or service based on perceptions of what is received and what they give (Zeithaml, 2000). Excellent customer value could be indicated by the fulfilment of service quality (Wong \& Wu, 2013). Even tough service quality does not directly influence customer satisfaction, it indirectly influences customer satisfaction through perceived value and customer equity (Hellier et al., 2003). Perceived value has a positive and significant link to loyalty; 
customers who receive value superiority will tend to be loyal and persuade it to others (Hu et al., 2009). Based on this background, the following hypotheses are proposed:

H2-1. Perceived value predicts service quality

H2-2. Perceived value moderates the link between service quality and repeat purchase

Total customer satisfaction defined as a person's feelings of pleasure or discomfort that result from comparing a product or service's perceived performance (or outcome) to expectancy (Kotler \& Keller, 2016), and that may fall under the price. If the performance or experience falls short of expectations, the customer is dissatisfied. Kotler \& Keller (2016) showed that if it meets expectancy, the customer is satisfied, while if it exceeds expectancy, the customer is highly satisfied or delighted. Hence, Cronin et al. (2000) emphasized customer satisfaction as customer's overall evaluation of a product or service in terms of whether that product or service has met their needs and expectancies as the result of customer perception of the value received. Based on those argumentations, we propose:

H3-1. Satisfaction predicts repeat purchase

H3-2. Satisfaction moderates the link between service quality and repeat purchase

Repeat purchase is one of the prominent factors in marketing since it increases revenue. Service quality of an initial purchase may relate to repeat purchases. However, the strength of their links depends on several variables, including perceived value and satisfaction. By knowing how good these variables moderate the link between service quality and repeat purchase, marketing practitioner could boost their sales. Therefore, the purpose of this study is to know if perceived value and satisfaction would moderate the link between service quality and repeat purchase. The framework of the conceptual model is shown in Fig. 1.

\section{Research Methodology}

The participants in this study are the 300 customers of PPM Manajemen. PPM Manajemen is a training institute for business and management courses located in Jakarta, Indonesia. This training institute offered more than a hundred different short courses every year and more than ten thousand enrollees every year. The customers of PPM Manajemen are companies. They sent their employee to take courses in this training institute. There were 90 courses offered by PPM Manajemen in the year 2019 which were analysed in this study.

Repeat purchase is the dependent variable of this study. It is measured by the number of participants who enrolled in each training course for the year 2019. When more participants enrol in the same course, it indicates that the same companies keep on sending their employee to take the same course. The more participants enroll indicates that the repeat purchase is higher.

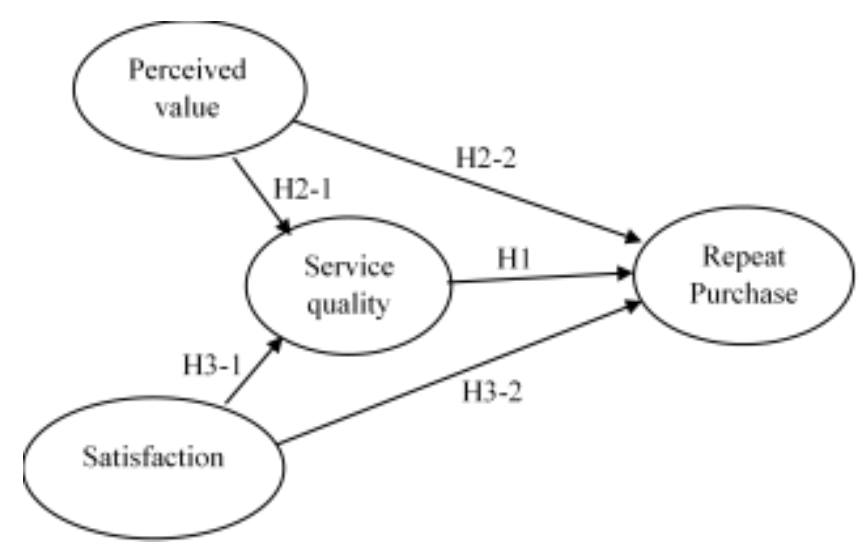

Figure 1. Conceptual model: the moderating effect of perceived value and satisfaction in the link between service quality and repeat purchase. 
The independent variable of this study is service quality. Service quality is a latent variable that was measured by three observable variables that were expressed in statements as follow. (1) The instructor delivers the material clearly; (2) The teaching method used is interesting; (3) The combination of theory and practice is balanced. The participants were pleased to respond to the statements, whether agree or disagree on a five-point Likert scale

There are two moderating variables in this study, perceived value, and satisfaction. Perceived value is determined by three reflective items as follows. (1) This training is beneficial for me; (2) The number of courses offered meets the needs; (3) The participation of other participants has met my expectations. They are formed into 5-point Likert scales. Satisfaction is measured by letting the participants select a score from 1 to 5 . One indicates very dissatisfaction to 5 very satisfied with the course they had attended. There is only one item asked, "In general, I feel satisfied with this training". The next step is testing the convergent validity. All items of perceived value have outer loading more than $70 \%$ as most research required (see Table 1)

Table 1. Convergent validity of perceived value

\begin{tabular}{cccc}
\hline & PV-Q1 & PV-Q2 & PV-Q3 \\
\hline Perceived Value & 0.866 & 0.906 & 0.715 \\
\hline
\end{tabular}

For service quality, the three items were tested for its convergent validity. As shown in Table 2, all of them have outer loading that is greater than 0,70 . Most research make use of outer loading greater than $70 \%$ to indicate that the items are convergently valid. In terms of discriminant validity, all constructs (perceived value, repeat purchase, satisfaction, and service quality) have average variance extracted which is higher than

Table 4. Cronbach alpha internal consistency and composite reliability

\begin{tabular}{|c|c|c|c|c|}
\hline & & Cronbach Alpha & \multicolumn{2}{|c|}{ Composite Reliability } \\
\hline Perceived Value & & 0.798 & \multicolumn{2}{|r|}{0.879} \\
\hline Satisfaction & & 1 & \multicolumn{2}{|r|}{1} \\
\hline Service Quality & & 0.888 & \multicolumn{2}{|r|}{0.931} \\
\hline & service Quallty & rescerved value & кepeal ruicilase & Salusiacuon \\
\hline Service Quality & 1.000 & & & \\
\hline Perceived Value & 0.337 & 0.833 & & \\
\hline Repeat Purchase & 0.214 & 0.143 & 1.000 & \\
\hline Satisfaction & 0.094 & 0.789 & 0.233 & 0.904 \\
\hline
\end{tabular}

\begin{tabular}{llllr}
\hline Service quality & 0.906 & 0.955 & 0.848 & the \\
correl
\end{tabular}

between that construct and the other constructs in the model, as shown in Table 3.

ation

Both the instrument for perceived value and service quality are reliable as indicated by both the Cronbach alpha internal consistency and the composite reliability, as shown in Table 4. The minimum required reliability score for most research is $70 \%$, and both the Cronbach alpha and composite reliability has score higher than 0.70. Partial Least Square (PLS) analysis technique is used to process data that is supported by a software application, namely Smart PLS. It is the most appropriate statistical tool, considering the sample size. The inner model's strength is determined by R2, while the significance of the inner model is measured by the beta coefficient. This technique also allows for the calculation of the direct and indirect impact of each relationship. 


\section{Results}

The null hypothesis that state no relationship between service quality and repeat purchase is rejected ( $\beta=$ $0.355, \mathrm{p}<0.05)$, as shown in Table 5. Service quality predicts repeat purchase. As quality of service increases, repeat purchase will also increase as the beta coefficient is positive.

Table 5. Significant of the inner model (hypothesized model)

\begin{tabular}{|c|c|c|}
\hline & $\beta$ Coefficient & P-Value \\
\hline Perceived Value $\rightarrow>$ Repeat purchase & -0.118 & 0.587 \\
\hline Perceived Value -> Service Quality & 0.501 & 0.000 \\
\hline Satisfaction $\quad \rightarrow$ Repeat Purchase & -0.044 & 0.808 \\
\hline -> Service Quality & 0.394 & 0.003 \\
\hline Service Quality -> Repeat Purchase & 0.355 & 0.036 \\
\hline
\end{tabular}

The null hypothesis that state perceived value and satisfaction do not moderate the relationship between service quality and repeat purchase are rejected. Perceived value significantly predicts service quality $(\beta=$ 0.501, $\mathrm{P}<0.05$ ), as shown in Table 5. As perceived value increases, service quality tends to increase too. However, there is no significant relationship between perceived value and repeat purchase $(\beta=-0.118, \mathrm{P}>$ $0.05)$. Satisfaction significantly predicts service quality $(\beta=0.394, \mathrm{P}<0.05)$, as shown in Table 5 . As satisfaction increases, service quality gets higher since the beta coefficient is positive. However, no significant relationship between satisfaction and repeat purchase $(\beta=-0.044, \mathrm{P}>0.05)$.

As shown in Figure 2, perceived value and satisfaction can explain $64.7 \%(\mathrm{R} 2=0.647)$ change in service quality. There is a direct effect of perceived value $(\beta=0.501)$ and satisfaction $(\beta=0.401)$ to service quality as stated in Table 6.

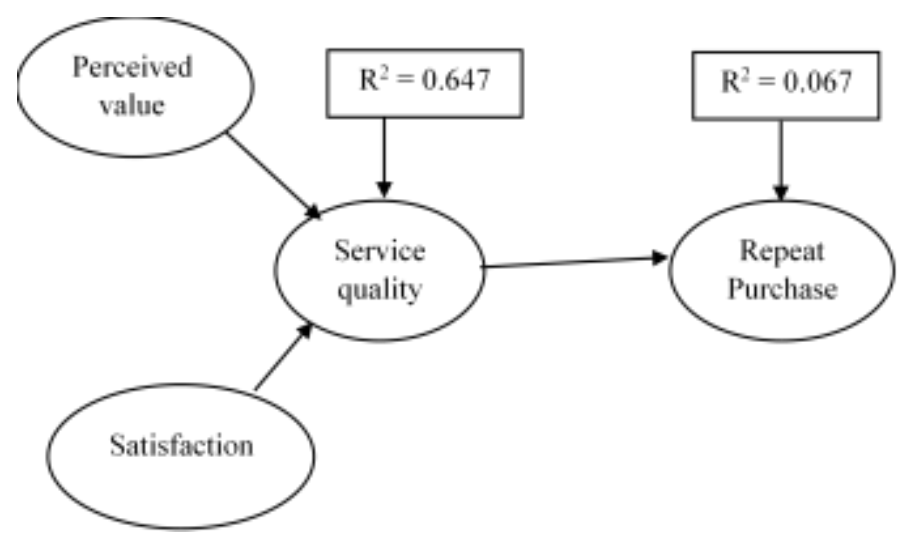

Figure 2. The final structural model of repeat purchase.

Table 6. Significant of the inner model (final model)

\begin{tabular}{|c|c|c|}
\hline & $\beta$ Coefficient & P-Value \\
\hline Perceived Value -> Service Quality & 0.501 & 0.000 \\
\hline Satisfaction $\quad \rightarrow$ Service Quality & 0.401 & 0.003 \\
\hline Service Quality $\quad>$ Repeat Purchase & 0.224 & 0.010 \\
\hline
\end{tabular}

However, there is an indirect effect of perceived value to repeat purchase $(\mathrm{r}=0.112)$, as shown in Table 7 . The total effect of perceived value to repeat purchase is $11.2 \%(\beta=0.112)$. For satisfaction, there is a positive direct effect $(\beta=0.224)$ and indirect effect $(\beta=0.09)$ to repeat purchase. As shown in Table 7 , the total effect 
of satisfaction to repeat purchase is $9 \%(\beta=0,09)$. Service quality can explain $6.7 \%(\mathrm{R} 2=0.067)$ change in repeat purchase.

Table 7. The indirect and total effect

\begin{tabular}{|c|c|c|}
\hline & Indirect Effect & Total Effect \\
\hline Perceived Value -> Repeat Purchase & 0.112 & 0.112 \\
\hline Satisfaction $\quad \rightarrow$ Repeat Purchase & 0.09 & 0.09 \\
\hline
\end{tabular}

\section{Discussion}

We examined a model of perceived value and satisfaction, which in turn imposes the link between service quality and repeat purchase. This study further investigated the independent role of three key determinants (perceived value, satisfaction, and service quality). These findings make several contributions to the current literature with the following ways:

First, we discover that service quality directly predicts repeat purchase. This finding supports Zeithaml et al. (1996) that states service quality is linked to behavioural consequences such as brand loyalty which we consider as a predisposition to repeat purchase since it induces loyalty toward the brand in a way will drive the consumer to rebuy the brand.

Second, perceived value does not directly support repeat purchase, and these findings provide insights in the relationship between perceived value-service quality-repeat purchase. Even if our results are up to a point corresponding with prior literature review (Batra et al., 1995), they strongly believe the relative insignificance of perceived value in the refinement of repeat purchase, notably respective to factor namely service quality as mediating variable which play a major role in linking both perceived value-repeat purchase.

The insignificance of the link between perceived value and repeat purchase in service sectors contributes toward enhancing theoretical knowledge of the perceived value effect. The literature shows that perceived value will result in an increased customer loyalty (Hu et al., 2009) which merely refers to repeat purchase, but in this study, perceived value is not directly related to repeat purchase. The findings suggest that perceived values are mediated by consumer experience in regards to service quality. That is, the effect of perceived value on repeat purchase is indirect and consumers seem to be forming their perceived values through service quality. Thus, managers should enhance their service quality through employee service training and service-oriented employee behaviour. Ha et al. (2014) indicate that service-oriented employee behaviour plays a key role in service encounters to maintain service quality standards and enhance customer experience and satisfaction. the crucial characteristic in a customer-oriented firm demonstrates organizational culture where a shared "set of beliefs puts customer interests first" (Deshpande et al., 1993). Service-oriented employee behaviour significantly impacts quality as perceived by customers by way of an individual experiential judgment on overall service-oriented employee behaviour which can be seen by magnificent concern of customer's favour (Wallin Andreassen, 1994; Boles et al., 2001).

Third, satisfaction does not directly underpin repeat purchase. This finding is the most challenging part of the overall results of the study due to most researchers believing that there is a direct link between customer satisfaction and repeat purchase. Among the figures who support this statement are as follows. Anwar et al. (2019) stated that there is a positive link between customer satisfaction and loyalty. Customers are more likely to use a product or service in a particular brand and become loyal to that brand if the customer is satisfied with what that brand has to offer. Research conducted by Marso \& Gunawan (2019) states that there is a positive and significant link between customer satisfaction and loyalty, which means that the more satisfied the customer is, the greater the likelihood that the customer will be loyal, such as making repeat purchases or recommending it to others. Furthermore, research conducted by Priyo et al. (2019) stated that 
customer satisfaction has a positively significant link to customer loyalty in the hotel industry. However, these mainstream findings contradict with the research conducted by Sukaisih \& Hamid (2015) that the positive link between customer satisfaction and loyalty at 3 star hotels in Malang and Batu states a low level of significance. We support the anti-mainstream findings.

\section{Conclusion}

Our empirical findings reveal that an extensive examination at the key determinants which impose repeat purchase is essential. We conclude that repeat purchases can occur when the quality of service is well designed. Service quality is a prerequisite for repeated customer purchases. Good service quality is obtained when there is a good perception of value and customer satisfaction. These two causal factors are significantly utilized as the biggest contributors to the creation of service quality.

Surprisingly, there is no single good service marketing strategy that works for all companies. Only service marketing strategies that specifically target consumers are the most successful. Efforts undertaken to improve service quality needs to be derived from customer point of view regarding what services need to be improved and in what ways the improvements are expected. Service redesign is also needed as an effort to improve service quality. Namely, when the customer started registering for training, they were greeted with warmth from the front liner. The easy to use platform to fill out the registration. Comprehensive information and real time which can be easily accessed by customers. They should also ensure that the service delivery is in accordance with the initial promise made by them.

Tiered-training for service providers (trainers and admin staffs) is also needed. Such training is expected to make them improve their level of service (namely aspects of reliability, assurance, tangible, empathy, and responsiveness). Gradually, it will improve service quality through the fulfilment of both perceived value and customer satisfaction. The lack of this study is that it focuses on internal elements of service providers such as perceived value, customer satisfaction, and service quality. Subsequent research can consider external elements such as competitor behaviour such as promotion activities conducted by competitors and the type of training offered by competitors. Other external factors such as customer situational factors such as purchasing power, self-development motivation, and purchasing risk factors for enrolling training services are also interesting to be further examined.

\section{References}

Andaleeb, S. S. (1998). Determinants of customer satisfaction with hospitals: a managerial model. International Journal of health care quality assurance. https://doi.org/10.1108/09526869810231541

Antón, C., Camarero, C., \& Carrero, M. (2007). The mediating effect of satisfaction on consumers' switching intention. Psychology \& Marketing, 24(6), 511-538. https://doi.org/10.1002/mar.20171

Antón, C., Camarero, C., \& Laguna-García, M. (2017). Towards a new approach of destination loyalty drivers: Satisfaction, visit intensity and tourist motivations. Current Issues in Tourism, 20(3), 238260.https://doi.org/10.1080/13683500.2014.936834

Anwar, S. A., \& Sohail, M. S. (2004). Festival tourism in the United Arab Emirates: First-time versus repeat visitor perceptions. Journal of Vacation Marketing, 10(2), 161-170.https://doi.org/10.1177\%2F135676670401000206

Anwar, S., Min, L., \& Dastagir, G. (2019). Effect of service quality, brand image, perceived value on customer satisfaction and loyalty in the Chinese banking industry. International Journal of Business, Economics and Management Works, 6(3), 24-30.

Batra, R., Lehmann, D. R., Burke, J., \& Pae, J. (1995). When does advertising have an impact? A study of tracking data. Journal of Advertising Research, 35, 19-32.

Boles, J. S., Babin, B. J., Brashear, T. G., \& Brooks, C. (2001). An examination of the relationships between retail work environments, salesperson selling orientation-customer orientation and job performance. Journal of Marketing Theory and Practice, 9(3), 1-13.https://doi.org/10.1080/10696679.2001.11501893 
Gray, B., \& Boshoff, C. (2004). The relationships between service quality, customer satisfaction and buying intentions in the private hospital industry. South African journal of business management, 35(4), 27-37. https://doi.org/10.4102/sajbm.v35i4.666

Brady, M. K., \& Robertson, C. J. (2001). Searching for a consensus on the antecedent role of service quality and satisfaction: an exploratory cross-national study. Journal of Business research, 51(1), 53-60. https://doi.org/10.1016/S0148-2963(99)00041-7

Chi, C. G. Q. (2012). An examination of destination loyalty: Differences between first-time and repeat visitors. Journal of Hospitality \& Tourism Research, 36(1), 3-24.https://doi.org/10.1177\%2F1096348010382235

Chua, B. L., Lee, S., \& Han, H. (2017). Consequences of cruise line involvement: A comparison of first-time and repeat passengers. International Journal of Contemporary Hospitality Management. https://doi.org/10.1108/IJCHM-09-20150452

Caceres, R. C., \& Paparoidamis, N. G. (2007). Service quality, relationship satisfaction, trust, commitment and business-to-business loyalty. European journal of marketing. https://doi.org/10.1108/03090560710752429

Cronin Jr, J. J., Brady, M. K., \& Hult, G. T. M. (2000). Assessing the effects of quality, value, and customer satisfaction on consumer behavioral intentions in service environments. Journal of retailing, 76(2), 193-218. https://doi.org/10.1016/S0022-4359\%2800\%2900028-2

Damit, D. H. D. A., Harun, A., Martin, D., Othman, B., \& Ahmad, H. (2019). What makes a non-Muslim purchase halal food in a Muslim country? An application of theory of planned behaviour. Management Science Letters, 9(12), 20292038. http://dx.doi.org/10.5267/j.msl.2019.7.003

Deshpandé, R., Farley, J. U., \& Webster Jr, F. E. (1993). Corporate culture, customer orientation, and innovativeness in Japanese firms: a quadrad analysis. Journal of marketing, 57(1), 23-37.https://doi.org/10.2307/1252055

Fakeye, P. C., \& Crompton, J. L. (1991). Image differences between prospective, first-time, and repeat visitors to the Lower Rio Grande Valley. Journal of travel research, 30(2), 10-16.https://doi.org/10.1177\%2F004728759103000202

Fullerton, G. (2005). How commitment both enables and undermines marketing relationships. European journal of marketing.https://doi.org/10.1108/03090560510623307

Ha, H. Y., Akamavi, R. K., Kitchen, P. J., \& Janda, S. (2014). Exploring key antecedents of purchase intentions within different services. Journal of Services Marketing.https://doi.org/10.1108/JSM-01-2013-0025

Hackman, D., Gundergan, S. P., Wang, P., \& Daniel, K. (2006). A service perspective on modelling intentions of online purchasing. Journal of Services Marketing. https://doi.org/10.1108/08876040610704892

Han, H., Hsu, L. T. J., Lee, J. S., \& Sheu, C. (2011). Are lodging customers ready to go green? An examination of attitudes, demographics, and eco-friendly intentions. International Journal of Hospitality Management, 30(2), 345-355. https://doi.org/10.1016/j.ijhm.2010.07.008

Han, H., \& Ryu, K. (2009). The roles of the physical environment, price perception, and customer satisfaction in determining customer loyalty in the restaurant industry. Journal of hospitality \& tourism research, 33(4), 487-510. https://doi.org/10.1177\%2F1096348009344212

Hellier, P. K., Geursen, G. M., Carr, R. A., \& Rickard, J. A. (2003). Customer repurchase intention. European journal of marketing. https://doi.org/10.1108/03090560310495456

Hu, H. H., Kandampully, J., \& Juwaheer, T. D. (2009). Relationships and impacts of service quality, perceived value, customer satisfaction, and image: an empirical study. The service industries journal, 29(2), 111-125. https://doi.org/10.1080/02642060802292932

Jones, M. A., Mothersbaugh, D. L., \& Beatty, S. E. (2000). Switching barriers and repurchase intentions in services. Journal of retailing, 76(2), 259-274. https://doi.org/10.1016/S0022-4359(00)00024-5

Kotler, P., \& Keller, K. L. (2015). Marketing management, global edition (pp. 194-209). Edinburgh Gate, England: Pearson Education Limited.

Lee, J. S., Lee, C. K., \& Yoon, Y. (2009). Investigating differences in antecedents to value between first-time and repeat festival-goers. Journal of Travel \& Tourism Marketing, 26(7), 688-702. https://doi.org/10.1080/10548400903284511

Lichtenstein, D. R., Bloch, P. H., \& Black, W. C. (1988). Correlates of price acceptability. Journal of consumer research, 15(2), 243-252.https://doi.org/10.1086/209161

Luo, J. G., Wong, I. A., King, B., Liu, M. T., \& Huang, G. (2019). Co-creation and co-destruction of service quality through customer-to-customer interactions. International Journal of Contemporary Hospitality Management. https://doi.org/10.1108/IJCHM-12-2017-0792 
Gunawan, S. (2019, October). A Structural Model of Service Quality, Perceived Value, Satisfaction, and Customer Loyalty in the Hotel Industry: A Case Study of Tarakan City, Indonesia. In 2019 International Conference on Organizational Innovation (ICOI 19). Atlantis Press.https://dx.doi.org/10.2991/icoi-19.2019.101

Musa, G., Doshi, D. R., Wong, K. M., \& Thirumoorthy, T. (2012). How satisfied are inbound medical tourists in Malaysia? A study on private hospitals in Kuala Lumpur. Journal of Travel \& Tourism Marketing, 29(7), 629-646. https://doi.org/10.1080/10548408.2012.720150

Oliver, R. L. (1999). Whence consumer loyalty?. Journal of marketing, 63(4_suppl1), 33-44. https://doi.org/10.1177\%2F00222429990634s105

Parasuraman, A., Zeithaml, V. A., \& Berry, L. L. (1988). Servqual: A multiple-item scale for measuring consumer perc. Journal of retailing, 64(1), 12.

Patterson, P. G., \& Smith, T. (2003). A cross-cultural study of switching barriers and propensity to stay with service providers. Journal of retailing, 79(2), 107-120.107-120. https://doi.org/10.1016/S0022-4359(03)00009-5

Patterson, P. G., \& Spreng, R. A. (1997). Modelling the relationship between perceived value, satisfaction and repurchase intentions in a business-to-business, services context: an empirical examination. International Journal of service Industry management. https://doi.org/10.1108/09564239710189835

Payne, A. (1999). Customer Relationship Management: Choosing the appropriate strategy and Data Warehousing technology to win and retain customers. In Customer Relationship Management (pp. 137-154). Vieweg+ Teubner Verlag, Wiesbaden. https://doi.org/10.1007/978-3-322-84961-8_15

Petrick, J. F. (2004). First timers' and repeaters' perceived value. Journal of Travel Research, 43(1), 29-38. https://doi.org/10.1177\%2F0047287504265509

Priyo, J. S., Mohamad, B., \& Adetunji, R. R. (2019). An examination of the effects of service quality and customer satisfaction on customer loyalty in the hotel industry. International Journal of Supply Chain Management, 8(1), 653663.

Rauyruen, P., \& Miller, K. E. (2007). Relationship quality as a predictor of B2B customer loyalty. Journal of business research, 60(1), 21-31. https://doi.org/10.1016/J.JBUSRES.2005.11.006

Rust, R. T., Lemon, K. N., \& Zeithaml, V. A. (2004). Return on marketing: Using customer equity to focus marketing strategy. Journal of marketing, 68(1), 109-127.https://doi.org/10.1509\%2Fjmkg.68.1.109.24030

Ryu, K., \& Han, H. (2011). New or repeat customers: How does physical environment influence their restaurant experience?. International Journal of Hospitality Management, 30(3), 599611.https://doi.org/10.1016/j.ijhm.2010.11.004

Sukaisih, E., Suharyono, S., \& Hamid, D. (2015). Effect of Functional Service Quality on Customer Satisfaction and Image and the Impact on Loyalty Intention (Study at ThreeStar Hotel in Malang City and Batu City). International Journal of Business and Management Invention, 4(2), 43-51.

Torres, E. N. (2014). Deconstructing service quality and customer satisfaction: Challenges and directions for future research. Journal of Hospitality Marketing \& Management, 23(6), 652-677. https://doi.org/10.1080/19368623.2014.846839

Taylor, S. A., \& Baker, T. L. (1994). An assessment of the relationship between service quality and customer satisfaction in the formation of consumers' purchase intentions. Journal of retailing, 70(2), 163-178. https://doi.org/10.1016/0022-4359(94)90013-2

Andreassen, T. W. (1994). Satisfaction, loyalty and reputation as indicators of customer orientation in the public sector. International Journal of Public Sector Management. https://doi.org/10.1108/09513559410055206

Wong, I. A., \& Wu, J. S. (2013). Understanding casino experiential attributes: An application to market positioning. International Journal of Hospitality Management, 35, 214-224.https://doi.org/10.1016/j.ijhm.2013.06.009

Zeithaml, V. A. (2000). Service quality, profitability, and the economic worth of customers: what we know and what we need to learn. Journal of the academy of marketing science, 28(1), 67-85.https://doi.org/10.1177/0092070300281007 Zeithaml, V., \& Bitner, M. J. (2003). Services Marketing, 3rd edt.

Zeithaml, V. A., Berry, L. L., \& Parasuraman, A. (1996). The behavioral consequences of service quality. Journal of marketing, 60(2), 31-46.https://doi.org/10.2307/1251929 